\title{
Reclassification of Serpulina intermedia and Serpulina murdochii in the genus Brachyspira as Brachyspira intermedia comb. nov. and Brachyspira murdochii comb. nov.
}

\author{
David J. Hampson and Tom La \\ School of Veterinary and Biomedical Sciences, Murdoch University, Murdoch, Western Australia \\ 6150, Australia
}

Correspondence

David J. Hampson

d.hampson@murdoch.edu.au

\begin{abstract}
A reassessment was undertaken of published characteristics of the five species of anaerobic intestinal spirochaetes in the genus Brachyspira (Brachyspira aalborgi, Brachyspira alvinipulli, Brachyspira hyodysenteriae, Brachyspira innocens and Brachyspira pilosicoli) and the two species in the genus Serpulina (Serpulina intermedia and Serpulina murdochii). Comparisons were made of published descriptions, including phenotypic properties, grouping by multilocus enzyme electrophoresis, DNA base composition, DNA-DNA relative reassociation values and 16S rRNA gene sequence similarity. On the basis of extensive similarities between all the species, it is proposed to reclassify Serpulina intermedia Stanton et al. 1997 and Serpulina murdochii Stanton et al. 1997 in the genus Brachyspira, as Brachyspira intermedia comb. nov. (type strain ATCC $51140^{\top}$ ) and Brachyspira murdochii comb. nov. (type strain ATCC $51284^{\top}$ ).
\end{abstract}

Anaerobic spirochaetes colonize the distal intestinal tracts of human beings and various species of animals and birds (Hampson \& Stanton, 1997). Currently, the two main genera of clinical interest are Brachyspira and Serpulina, as they include pathogenic as well as commensal species. The genus Brachyspira, originally containing the single species Brachyspira aalborgi, was proposed in 1982 (HovindHougen et al., 1982). B. aalborgi colonizes humans and its pathogenicity remains uncertain. The genus Serpulina, containing the species Serpulina hyodysenteriae and Serpulina innocens, was proposed by Stanton (1992). These two species colonize pigs and were originally allocated to the genus Treponema as Treponema hyodysenteriae, the agent of swine dysentery (Harris et al., 1972), and the non-pathogenic Treponema innocens (Kinyon \& Harris, 1979). Subsequently, both species were transferred briefly to the proposed new genus Serpula (Stanton et al., 1991). Because this genus name was discovered to be illegitimate due to the prior existence of the fungal genus Serpula, both species were then reclassified in the new genus Serpulina. A third Serpulina species, Serpulina pilosicoli, was proposed in 1996 (Trott et al., 1996b). S. pilosicoli was pathogenic to pigs and chickens and colonized humans and many species of animals and birds. Subsequently, it was proposed that the

Abbreviation: MLEE, multilocus enzyme electrophoresis.

The GenBank/EMBL/DDBJ accession numbers for the 16S rRNA gene sequences of Brachyspira intermedia ATCC 51140 ${ }^{\top}$ and Brachyspira murdochii ATCC $51284^{\top}$ are $\mathrm{U} 23033$ and AY312492, respectively. genera Serpulina and Brachyspira be unified and that S. hyodysenteriae, S. innocens and S. pilosicoli be transferred to the genus Brachyspira, as Brachyspira hyodysenteriae comb. nov., Brachyspira innocens comb. nov. and Brachyspira pilosicoli comb. nov. (Ochiai et al., 1997). These new name combinations appeared in Validation List no. 64 (Ochiai et al., 1998). Concurrently, a description of the novel species Serpulina alvinipulli was published, with the updated name Brachyspira alvinipulli added in proof in response to the transfer of the three other former Serpulina species to the genus Brachyspira (Stanton et al., 1998). Two further Serpulina species, Serpulina intermedia and Serpulina murdochii, were proposed in 1997 (Stanton et al., 1997). Unfortunately, due to the timing of their description, they were not included in the transfer of species when the genera Serpulina and Brachyspira were unified in 1997. This situation has since been a source of some confusion, with various authors now pragmatically electing to call the two remaining Serpulina species 'Brachyspira intermedia' and 'Brachyspira murdochii, respectively, rather than the validly published names S. intermedia and S. murdochii.

The current paper proposes the transfer of S. intermedia and S. murdochii to the genus Brachyspira. In support of this proposal, published data relating to the five current Brachyspira species and the two Serpulina species (Stanton et al., 1991, 1996, 1997, 1998; Ochiai et al., 1997) were reassessed. All seven species are slow-growing anaerobic spirochaetes that colonize the distal intestinal tract. All seven have a low $\mathrm{G}+\mathrm{C}$ content, with values for the type strains of the 
species varying in the range $24.6 \mathrm{~mol} \%$ for B. alvinipulli ATCC $51933^{\mathrm{T}}$ (Stanton et al., 1998) to $27 \cdot 1 \mathrm{~mol} \%$ for B. aalborgi NTCC $11492^{\mathrm{T}}$ (Ochiai et al., 1997). S. intermedia ATCC $51140^{\mathrm{T}}$ has a $\mathrm{G}+\mathrm{C}$ content of $25 \mathrm{~mol} \%$ and S. murdochii ATCC $51284^{\mathrm{T}}$ a $\mathrm{G}+\mathrm{C}$ content of $27 \mathrm{~mol} \%$ (Stanton et al., 1997). In a study using multilocus enzyme electrophoresis (MLEE) and partial sequencing of the 16S rRNA gene to analyse strains of the seven intestinal spirochaete species, these species were clustered together, with $B$. aalborgi being the most distantly related of the species (Stanton et al., 1996). These results are consistent with the two Serpulina species belonging to the same genus as the Brachyspira species. To illustrate these relationships, partial (1205 bp) 16S rRNA gene sequences of the seven type strains were obtained from the DDBJ/GenBank/EMBL databases and used to create a dendrogram (Fig. 1). Again, B. aalborgi appears as the outlying species. Pairwise alignments of these sequences for the seven type strains gave similarity values in the range $95 \cdot 5-99 \cdot 7 \%$, consistent with the species belonging to the same genus (Ochiai et al., 1997). S. intermedia ATCC $51140^{\mathrm{T}}$ was most closely related to B. hyodysenteriae ATCC $27164^{\mathrm{T}}(99 \cdot 7 \%$ similarity), whereas S. murdochii was most closely related to B. innocens ATCC $29796^{\mathrm{T}}$ (99.4\% similarity).

If the seven species belong to the same genus, the question then arises as to whether the two remaining Serpulina species are distinct from the current five Brachyspira species. Arguments in support of separate species identity were made at the time that $S$. intermedia and $S$. murdochii were described (Stanton et al., 1997) and are reiterated. $B$. hyodysenteriae is the species most closely related to $S$. intermedia. Besides their almost identical $16 \mathrm{~S}$ rRNA gene sequences, DNA from the type strains of B. hyodysenteriae and S. intermedia showed $57-68 \%$ relative reassociation (Stanton et al., 1997), closely approaching the value of $70 \%$ that is usually used to indicate that two strains belong to the same species (Wayne et al., 1987). Furthermore, they share a number of phenotypic properties: both produce indole and typically have $\alpha$-glucosidase and $\beta$-glucosidase activity when tested in the commercial API ZYM system (Lee et al., 1993; Fellström \& Gunnarsson, 1995). However, the two species can be distinguished by MLEE analysis (Stanton et al., 1996) and on the basis of consistent differences in the sequences of their 23S rRNA genes (Leser et al., 1997) and their NADH oxidase genes (Atyeo et al., 1999). A notable feature of B. hyodysenteriae is that it produces a strong $\beta$-haemolysis on blood agar, whereas $S$. intermedia produces weak haemolysis. Infection of the porcine colon with $B$. hyodysenteriae induces a severe mucohaemorrhagic diarrhoea (swine dysentery), whereas $S$. intermedia is generally not considered to be pathogenic in pigs (Harris et al., 1999). Hence the two species have clear phenotypic and biological differences that can be used to differentiate them.

The second Serpulina species, S. murdochii, is most closely related to $B$. innocens. These two species have very similar $16 \mathrm{~S}$ rRNA gene sequences and the type strains have 64-66\% DNA-DNA relative reassociation (Stanton et al., 1997), which again is borderline in terms of differentiating species (Wayne et al., 1987). However, they clearly cluster in different groups in MLEE analysis (Stanton et al., 1996; McLaren et al., 1997) and can be separated on the basis of differences in their NADH oxidase gene sequences (Atyeo et al., 1999) and by restriction fragment length polymorphism analysis of PCR-generated 16S rRNA gene products (Stanton et al., 1998). They also have minor phenotypic differences, with $B$. innocens typically being $\alpha$-galactosidase-positive whereas S. murdochii is typically negative for this activity (Lee et al., 1993; Fellström \& Gunnarsson, 1995). These differences are sufficient to allow them to be distinguished as separate species.

Taken together, these data demonstrate that the seven named species of anaerobic intestinal spirochaetes are

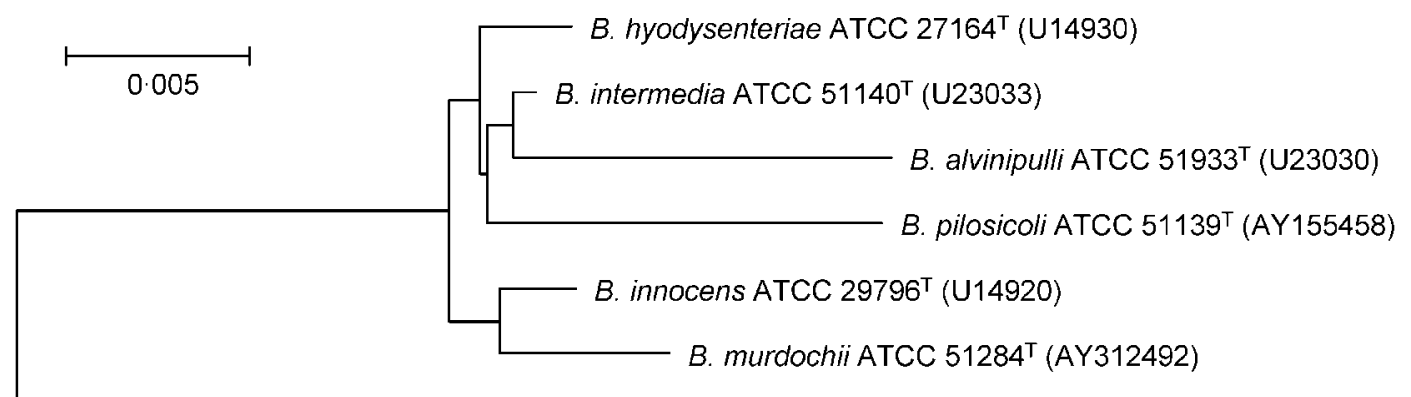

B. aalborgi NTCC $11492^{\top}(\mathrm{Z} 22781)$

Fig. 1. Unrooted phylogenetic tree of the genus Brachyspira and related proposed species $B$. intermedia comb. nov. and $B$. murdochii comb. nov. The tree was generated using the neighbour-joining method (Saitou \& Nei, 1987) based on partial (1205 bp) 16S rRNA gene sequences retrieved from the DDBJ/GenBank/EMBL databases (accession numbers are given in parentheses). Phylogenetic distance values were generated using MEGA version 3.0 (Kumar et al., 2004) and the JukesCantor model was used to account for nucleotide substitutions. Bar, relative sequence divergence (5 estimated substitutions per 1000 base positions). 
distinct, but are closely related, and that it is appropriate that they be unified in a single genus. The genus name Brachyspira has chronological precedence over the name Serpulina and hence all seven species should be located in the genus Brachyspira. Therefore, we propose the transfer of Serpulina intermedia and Serpulina murdochii to the genus Brachyspira, as Brachyspira intermedia comb. nov. (type strain ATCC $51140^{\mathrm{T}}$ ) and Brachyspira murdochii comb. nov. (type strain ATCC $51284^{\mathrm{T}}$ ).

\section{Description of Brachyspira intermedia comb. nov.}

Brachyspira intermedia [in.ter.me'di.a. L. fem. adj. intermedia that is between, intermediate, referring to the fact that the biochemical reactivities of this organism are intermediate between those characteristically possessed by $B$. hyodysenteriae and by B. innocens (Lee et al., 1993)].

Basonym: Serpulina intermedia Stanton et al. 1997.

Previously also known as 'Serpulina intermedius' (Lee et al., 1993). Some intestinal spirochaetes referred to as 'Treponema hyodysenteriae' biotype 2 or 'intermediate type' may be B. intermedia strains (Binek \& Szynkiewicz, 1984).

B. intermedia strains have been isolated from commercial poultry flocks exhibiting diarrhoea and reduced production (McLaren et al., 1997; Stephens et al., 2005), and experimental infection of laying hens with a pure culture of a $B$. intermedia strain has caused reduced egg production and increased faecal water content (Hampson \& McLaren, 1999). The description is as given previously by Stanton et al. (1997).

The type strain is ATCC $51140^{\mathrm{T}}\left(=\operatorname{CIP} 105833^{\mathrm{T}}\right)$.

\section{Description of Brachyspira murdochii comb. nov.}

Brachyspira murdochii (mur.do'chi.i. N.L. masc. gen. n. murdochii of Murdoch, in recognition of work conducted at Murdoch University in Western Australia, where the type strain was identified).

Basonym: Serpulina murdochii Stanton et al. 1997.

Previously known as 'group B spirochaetes' and S. murdochii (Lee et al., 1993; Lee \& Hampson, 1994). B. murdochii strains have been isolated from the large intestinal contents of healthy swine and rats (Trott et al., 1996a) and from chickens (Stephens et al., 2005). The spirochaete generally is not considered to be a pathogen, although occasionally it has been seen in association with colitis in pigs (Weissenbock et al., 2005). The description is as given previously by Stanton et al. (1997).

The type strain is ATCC $51284^{\mathrm{T}}\left(=\mathrm{CIP} 105832^{\mathrm{T}}=\mathrm{DSM}\right.$ $\left.12563^{\mathrm{T}}\right)$.

\section{References}

Atyeo, R. F., Stanton, T. B., Jensen, N. S., Suriyaarachichi, D. S. \& Hampson, D. J. (1999). Differentiation of Serpulina species by $\mathrm{NADH}$ oxidase gene (nox) sequence comparisons and nox-based polymerase chain reaction tests. Vet Microbiol 67, 47-60.

Binek, M. \& Szynkiewicz, Z. M. (1984). Physiological properties and classification of strains of Treponema sp. isolated from pigs in Poland. Comp Immunol Microbiol Infect Dis 7, 141-148.

Fellström, C. \& Gunnarsson, A. (1995). Phenotypical characterisation of intestinal spirochaetes isolated from pigs. Res Vet Sci 59, $1-4$.

Hampson, D. J. \& McLaren, A. J. (1999). Experimental infection of layer hens with Serpulina intermedia causes reduced egg production and increased faecal water content. Avian Pathol 28, 113-117.

Hampson, D. J. \& Stanton, T. B. (1997). Intestinal Spirochaetes in Domestic Animals and Humans. Wallingford, UK: CAB International.

Harris, D. L., Glock, R. D., Christensen, C. R. \& Kinyon, J. M. (1972). Inoculation of pigs with Treponema hyodysenteriae (new species) and reproduction of the disease. Vet Med Small Anim Clin 67, 61-64.

Harris, D. L., Hampson, D. J. \& Glock, R. (1999). Swine dysentery. In Diseases of Swine, 8th edn, pp. 579-600. Edited by B. E. Straw, S. D’Allaire, W. L. Mengeling \& D. J. Taylor. Ames, IA: Iowa State University Press.

Hovind-Hougen, K., Birch-Andersen, A., Hendrik-Nielsen, R., Orholm, M., Pedersen, J. O., Teglbjærg, P. S. \& Thaysen, E. H. (1982). Intestinal spirochetosis: morphological characterization and cultivation of the spirochete Brachyspira aalborgi gen. nov., sp. nov. J Clin Microbiol 16, 1127-1136.

Kinyon, J. M. \& Harris, D. L. (1979). Treponema innocens, a new species of intestinal bacteria, and emended description of the type strain of Treponema hyodysenteriae Harris et al. Int J Syst Bacteriol 29, 102-109.

Kumar, S., Tamura, K. \& Nei, M. (2004). MEGA3: integrated software for molecular evolutionary genetics analysis and sequence alignment. Brief Bioinform 5, 150-163.

Lee, J. I. \& Hampson, D. J. (1994). Genetic characterisation of intestinal spirochaetes and their association with disease. $J \mathrm{Med}$ Microbiol 40, 365-371.

Lee, J. I., Hampson, D. J., Lymbery, A. J. \& Harders, S. J. (1993). The porcine intestinal spirochaetes: identification of new genetic groups. Vet Microbiol 34, 273-285.

Leser, T. D., Møller, M., Jensen, T. K. \& Jorsal, S. E. (1997). Specific detection of Serpulina hyodysenteriae and potentially pathogenic weakly $\beta$-haemolytic porcine intestinal spirochetes by polymerase chain reaction targeting 23S rDNA. Mol Cell Probes 11, 363-372.

McLaren, A. J., Trott, D. J., Swayne, D. E., Oxberry, S. L. \& Hampson, D. J. (1997). Genetic and phenotypic characterization of intestinal spirochetes colonizing chickens and allocation of known pathogenic isolates to three distinct genetic groups. J Clin Microbiol 35, 412-417.

Ochiai, S., Adachi, Y. \& Mori, K. (1997). Unification of the genera Serpulina and Brachyspira, and proposals of Brachyspira hyodysenteriae comb. nov., Brachyspira innocens comb. nov. and Brachyspira pilosicoli comb. nov. Microbiol Immunol 41, 445-452.

Ochiai, S., Adachi, Y. \& Mori, K. (1998). Brachyspira hyodysenteriae comb. nov., Brachyspira innocens comb. nov. and Brachyspira pilosicoli comb. nov. In Validation of Publication of New Names and New Combinations Previously Effectively Published Outside the IJSEM, List no. 64. Int J Syst Bacteriol 48, 327-328. 
Saitou, N. \& Nei, M. (1987). The neighbor-joining method: a new method for reconstructing phylogenetic trees. Mol Biol Evol 4, 406-425.

Stanton, T. B. (1992). Proposal to change the genus designation Serpula to Serpulina gen. nov. containing the species Serpulina hyodysenteriae comb. nov. and Serpulina innocens comb. nov. Int J Syst Bacteriol 42, 189-190.

Stanton, T. B., Jensen, N. S., Casey, T. A., Tordoff, L. A., Dewhirst, F. E. \& Paster, B. J. (1991). Reclassification of Treponema hyodysenteriae and Treponema innocens in a new genus, Serpula gen. nov., as Serpula hyodysenteriae comb. nov. and Serpula innocens comb. nov. Int J Syst Bacteriol 41, 50-58.

Stanton, T. B., Trott, D. J., Lee, J. I., McLaren, A. J., Hampson, D. J., Paster, B. J. \& Jensen, N. S. (1996). Differentiation of intestinal spirochaetes by multilocus enzyme electrophoresis analysis and 16S rRNA sequence comparisons. FEMS Microbiol Lett 136, 181-186.

Stanton, T. B., Fournié-Amazouz, E., Postic, D., Trott, D. J., Grimont, P. A. D., Baranton, G., Hampson, D. J. \& Saint Girons, I. (1997). Recognition of two new species of intestinal spirochetes: Serpulina intermedia sp. nov. and Serpulina murdochii sp. nov. Int J Syst Bacteriol 47, 1007-1012.
Stanton, T. B., Postic, D. \& Jensen, N. S. (1998). Serpulina alvinipulli sp. nov., a new Serpulina species that is enteropathogenic for chickens. Int J Syst Bacteriol 48, 669-676.

Stephens, C. P., Oxberry, S. L., Phillips, N. D., La, T. \& Hampson, D. J. (2005). The use of multilocus enzyme electrophoresis to characterise intestinal spirochaetes (Brachyspira spp.) colonising hens in commercial flocks. Vet Microbiol 107, 149-157.

Trott, D. J., Atyeo, R. F., Lee, J. I., Swayne, D. E., Stoutenburg, J. W. \& Hampson, D. J. (1996a). Genetic relatedness amongst intestinal spirochaetes isolated from rats and birds. Lett Appl Microbiol 23, 431-436.

Trott, D. J., Stanton, T. B., Jensen, N. S., Duhamel, G. E., Johnson, J. L. \& Hampson, D. J. (1996b). Serpulina pilosicoli sp. nov., the agent of porcine intestinal spirochetosis. Int J Syst Bacteriol 46, 206-215.

Wayne, L. G., Brenner, D. J., Colwell, R. R. \& 9 other authors (1987). Report of the ad hoc committee on reconciliation of approaches to bacterial systematics. Int J Syst Bacteriol 37, 463-464.

Weissenbock, H., Maderner, A., Herzog, A. M., Lussy, H. \& Nowotny, N. (2005). Amplification and sequencing of Brachyspira spp. specific portions of nox using paraffin-embedded tissue samples from clinical colitis in Austrian pigs shows frequent solitary presence of Brachyspira murdochii. Vet Microbiol 111, 67-75. 